\title{
The positive of stool test for SARS-CoV-2: a report of 9 cases in Changsha, outside Wuhan, China
}

\author{
Yang Zhou ${ }^{1 \#}$, Ning Ding ${ }^{1 \#}$, Min $\mathrm{Hu}^{2}$, Guifang Yang ${ }^{1}$ \\ ${ }^{1}$ Department of Emergency Medicine, The Second Xiangya Hospital, Emergency Medicine and Difficult Disease Institute, Central South University, \\ Changsha 410011, China; ${ }^{2}$ Department of Laboratory Medicine, The Second Xiangya Hospital, Central South University, Changsha 410011, China \\ \#The authors contributed equally to this work. \\ Correspondence to: Guifang Yang. Department of Emergency Medicine, The Second Xiangya Hospital, Emergency Medicine and Difficult Disease \\ Institute, Central South University, No. 139 Renmin Road, Changsha 410011, China. Email: yangguifang@csu.edu.cn; Min Hu. Department of \\ Laboratory Medicine, The Second Xiangya Hospital, Central South University, No. 139 Renmin Road, Changsha 410011, China. \\ Email: huminjyk@csu.edu.cn.
}

Submitted Mar 03, 2020. Accepted for publication Apr 15, 2020.

doi: $10.21037 /$ atm-20-2165

View this article at: http://dx.doi.org/10.21037/atm-20-2165

In December 2019, several patients with viral pneumonia were identified to be related to the Huanan seafood market in Wuhan, in the Hubei province of China (1). By Feb 21, 2020, China has reported 77,269 patients confirmed the 2019 novel coronavirus disease (COVID-19) and caused 2,596 cases of death. Studies have suggested that personto-person transmission has occurred among close contacts since the middle of December 2019 (2). Respiratory droplet transmission was the primary route of transmission, and it can also be transmitted through contact (3). The first confirmed case of COVID-19 in the United States showed that a sample of stool tested positive by real-time RT-PCR for severe acute respiratory syndrome coronavirus 2 (SARS$\mathrm{CoV}-2)$ (4). Additionally, a bioinformatics analysis based on single-cell transcriptomes revealed that the digestive system was a potential route of SARS-CoV-2 infection (5). The source of the virus and its ability to spread between people may also be transmitted through fecal-oral transmission. However, the knowledge of clinical manifestations of patients with SARS-CoV-2 positive in the stool test is limited.

Nine patients with SARS-CoV-2 positive in the stool test were admitted to the Second Xiangya Hospital of Central South University, Changsha, China in February 2020. Their clinical data were collected and all of them were transferred to The First Hospital of Changsha (Changsha Public Health Treatment Center) after being diagnosed. The SARS-CoV-2 RNA extraction procedure was performed with the Viral Nucleic Acid Isolation Kit (Jiangsu bioPerfectus Technologies Co., Ltd., China) according to the manufacturer's instructions. The initial respiratory specimens (oropharyngeal swabs) were obtained from these patients' admission. Stools were obtained on admission or the next day.

In general, the median age of the patients was 53 years old. The youngest patient was 37 years old, while the oldest one was 70 years old. Of the nine patients, five were male and four were female. All of the nine patients had a history of contact with the people who were diagnosed with COVID-19 and eight patients had Wuhan exposure history. There were three patients who had diarrhea. Laboratory findings including the level of C-reactive protein increased significantly in all patients. All patients' samples of throat swab and stool for SARS-CoV-2 RT-PCR testing were positive. Except for one patient without lung lesion on computed tomography scan (CTs), chest images of the other eight patients showed patchy ground-glass opacities or/and consolidations, especially around the peripheral parts of the lungs on CTs. One patient had complications including acute respiratory distress syndrome (ARDS) and acute kidney injury (AKI). The patients received antiviral therapy, symptom management, and oxygen support. As of February 12, 2020, two of the patients recovered, but seven were still being quarantined in the hospital (Table 1).

To the best of our knowledge, this is the first descriptive study on the clinical characteristics of the patients with a 
Table 1 Characteristics of patients with SARS-CoV-2 positive in stool test

\begin{tabular}{|c|c|}
\hline Characteristics & $\begin{array}{c}\text { Overall, mean } \\
\text { (SD)/No. (\%) }\end{array}$ \\
\hline \multicolumn{2}{|l|}{ Baseline } \\
\hline Age, median (IQR), y & $\begin{array}{c}53.00 \\
(41.00-67.00)\end{array}$ \\
\hline Gender (male) & $5(55.56 \%)$ \\
\hline Wuhan exposure & $8(88.89 \%)$ \\
\hline Smoking & $5(55.56 \%)$ \\
\hline Hypertension & $2(22.22 \%)$ \\
\hline Diabetes & $1(11.11 \%)$ \\
\hline Cardiovascular disease & $0(0 \%)$ \\
\hline COPD & $1(11.11 \%)$ \\
\hline Malignancy & $0(0 \%)$ \\
\hline Chronic liver disease & $0(0 \%)$ \\
\hline Fever & $8(88.89 \%)$ \\
\hline Highest temperature, ${ }^{\circ} \mathrm{C}$ & $38.02 \pm 0.76$ \\
\hline Cough & $5(55.56 \%)$ \\
\hline Fatigue & $7(77.78 \%)$ \\
\hline Expectoration & $4(44.44 \%)$ \\
\hline Headache & $5(55.56 \%)$ \\
\hline Vomiting & $0(0 \%)$ \\
\hline Diarrhea & $3(33.33 \%)$ \\
\hline The onset of symptom to hospital admission, $d$ & $6.56 \pm 3.61$ \\
\hline Systolic pressure, $\mathrm{mmHg}$ & $127.44 \pm 23.96$ \\
\hline Diastolic pressure, $\mathrm{mmHg}$ & $72.11 \pm 9.78$ \\
\hline Heart rate, per min & $91.44 \pm 13.31$ \\
\hline Respiratory rate, per min & $19.78 \pm 0.67$ \\
\hline $\mathrm{SPO}_{2}, \%$ & $96.56 \pm 1.13$ \\
\hline \multicolumn{2}{|l|}{ Laboratory testing } \\
\hline White blood cell count, $\times 10^{9} / \mathrm{L}$ & $5.22 \pm 2.69$ \\
\hline Red blood cell count, $\times 10^{9} / \mathrm{L}$ & $4.34 \pm 0.87$ \\
\hline Neutrophil count, $\times 10^{9} / \mathrm{L}$ & $3.75 \pm 2.64$ \\
\hline Lymphocyte count, $\times 10^{9} / \mathrm{L}$ & $1.07 \pm 0.52$ \\
\hline Hemoglobin, g/L & $128.56 \pm 27.58$ \\
\hline Platelet count, $\times 10^{9} / \mathrm{L}$ & $175.67 \pm 82.44$ \\
\hline Prothrombin time, $\mathrm{s}$ & $12.19 \pm 0.71$ \\
\hline
\end{tabular}

Table 1 (continued)
Table 1 (continued)

\begin{tabular}{|c|c|}
\hline Characteristics & $\begin{array}{l}\text { Overall, mean } \\
(\mathrm{SD}) / \text { No. }(\%)\end{array}$ \\
\hline Activated partial thromboplastin time, $\mathrm{s}$ & $33.59 \pm 3.28$ \\
\hline D-dimer, mg/L & $0.40 \pm 0.28$ \\
\hline Alanine aminotransferase, U/L & $29.15 \pm 11.01$ \\
\hline Aspartate aminotransferase, U/L & $26.69 \pm 10.36$ \\
\hline Albumin, $g / L$ & $36.34 \pm 5.23$ \\
\hline Total bilirubin, $\mathrm{mmol} / \mathrm{L}$ & $10.18 \pm 2.98$ \\
\hline Direct bilirubin, $\mathrm{mmol} / \mathrm{L}$ & $3.32 \pm 1.05$ \\
\hline Serum $\mathrm{K}^{+}, \mathrm{mmol} / \mathrm{L}$ & $4.05 \pm 0.63$ \\
\hline Serum $\mathrm{Na}^{+}, \mathrm{mmol} / \mathrm{L}$ & $134.33 \pm 2.70$ \\
\hline Creatinine, $\mu \mathrm{mol} / \mathrm{L}(\mathrm{IQR})$ & $\begin{array}{c}48.30 \\
(44.77-63.37)\end{array}$ \\
\hline Blood urea nitrogen, $\mathrm{mmol} / \mathrm{L}$ & $5.46 \pm 3.21$ \\
\hline Lactate dehydrogenase, U/L & $201.18 \pm 51.01$ \\
\hline Troponin $\mathrm{T},<100 \mathrm{pg} / \mathrm{mL}$ & $9(100 \%)$ \\
\hline Creatine kinase, U/L & $114.74 \pm 110.40$ \\
\hline Creatine kinase-MB, U/L & $16.26 \pm 13.46$ \\
\hline Procalcitonin, ng/mL & $0.09 \pm 0.07$ \\
\hline C-reactive protein, $\mathrm{mg} / \mathrm{L}$ & $31.27 \pm 20.04$ \\
\hline Cycle threshold of throat swab & $32.95 \pm 5.58$ \\
\hline Cycle threshold of stool & $33.68 \pm 4.46$ \\
\hline \multicolumn{2}{|l|}{ Chest CTs findings } \\
\hline Unilateral pneumonia & $1(11.11 \%)$ \\
\hline Bilateral pneumonia & $5(55.56 \%)$ \\
\hline Multiple mottling and ground-glass opacity & $2(22.22 \%)$ \\
\hline \multicolumn{2}{|l|}{ Complications } \\
\hline ARDS & $1(11.11 \%)$ \\
\hline Acute cardiac injury & $0(0 \%)$ \\
\hline AKI & $1(11.11 \%)$ \\
\hline Shock & $0(0 \%)$ \\
\hline \multicolumn{2}{|l|}{ Treatment } \\
\hline Antiviral therapy & $9(100.00 \%)$ \\
\hline Antibiotic therapy & $3(33.33 \%)$ \\
\hline Use of corticosteroid & $3(33.33 \%)$ \\
\hline Probiotics & $7(77.78 \%)$ \\
\hline
\end{tabular}

Table 1 (continued) 
Table 1 (continued)

\begin{tabular}{lc}
\hline Characteristics & $\begin{array}{c}\text { Overall, mean } \\
(\mathrm{SD}) / \text { No. }(\%)\end{array}$ \\
\hline CRRT & $0(0 \%)$ \\
Oxygen inhalation & $7(77.78 \%)$ \\
Nasal cannula & $2(22.22 \%)$ \\
High flow & \\
Outcomes & $7(77.78 \%)$ \\
Hospitalization & $2(22.22 \%)$ \\
Discharge & $0(0 \%)$ \\
Death & \\
\hline
\end{tabular}

COPD, chronic obstructive pulmonary disease; IQR, interquartile range; SARS-CoV-2, severe acute respiratory syndrome coronavirus 2; ND, not detected; CTs, computed tomography scan; ARDS, acute respiratory distress syndrome; AKI, acute kidney injury; CRRT, continuous renal replacement therapy.

positive stool test of SARS-CoV-2. The results showed that patients onset 3 through 13 days, and both viral tests of stool and respiratory specimens were positive. We found that all nine patients had a positive stool test, but we can't make a conclusion whether they were infected by fecal-oral transmission.

Studies reported that SARS-CoV-2 infected cases had symptoms like fever, fatigue, dry cough, dyspnea, etc., with or without nasal congestion, runny nose or other upper respiratory symptoms (6). In our study, out of nine patients whose stool sample tested positive, five displayed symptoms of respiratory issues, three had diarrhea, and all of them had a fever. Furthermore, eight patients in our study have developed the Novel Coronavirus Pneumonia (NCP). From our review, the patients with SARS-CoV-2 positive in stool test may not have any difference with the other COVID-19 patients. Chen et al. (7) suggested that SARS-CoV-2 infection was more likely to affect older males with comorbidities and can result in severe and even fatal respiratory disorders such as ARDS. Our results showed that an older female with diabetes mellitus (DM) and hypertension was developed ARDS and AKI. This could be explained by comorbidities leading to severe respiratory disease or other complications.

In the study of these patients, we identified that the SARS-CoV-2 virus survived in the stool, which was a new source of infection. However, we couldn't make the conclusion that there is a new route of transmission of the virus, and further research needs to be verified of the possible existence of fecal-oral transmission. In addition, imperfect toilet drainage systems in most rural areas of China may result in a greater risk of SARS-CoV-2 exposure. Necessary precautions need to be taken in order to prevent the spread of the virus.

This study has some limitations. Stool tests with SARSCoV-2 have not been performed in all the patients with COVID-19 and most patients are still being hospitalized, which makes it difficult to assess any further clinical outcomes.

\section{Acknowledgments}

The authors thank all staff members in our institution and The First Hospital of Changsha.

Funding: None.

\section{Footnote}

Conflicts of Interest: All authors have completed the ICMJE uniform disclosure form (available at http://dx.doi. org/10.21037/atm-20-2165). The authors have no conflicts of interest to declare.

Ethical Statement: The authors are accountable for all aspects of the work in ensuring that questions related to the accuracy or integrity of any part of the work are appropriately investigated and resolved. The study was approved by the ethics board of the Second Xiangya Hospital of Central South University (NO.: LYF2020044) and informed consent was waived due to its retrospective nature.

Open Access Statement: This is an Open Access article distributed in accordance with the Creative Commons Attribution-NonCommercial-NoDerivs 4.0 International License (CC BY-NC-ND 4.0), which permits the noncommercial replication and distribution of the article with the strict proviso that no changes or edits are made and the original work is properly cited (including links to both the formal publication through the relevant DOI and the license). See: https://creativecommons.org/licenses/by-nc-nd/4.0/.

\section{References}

1 Huang C, Wang Y, Li X, et al. Clinical features of patients infected with 2019 novel coronavirus in Wuhan, China. 
Lancet 2020;395:497-506.

2 Chan JF, Yuan S, Kok K, et al. A familial cluster of pneumonia associated with the 2019 novel coronavirus indicating person-to-person transmission: a study of a family cluster. Lancet 2020;395:514-23.

3 Kim JY, Choe PG, Oh Y, et al. The first case of 2019 novel coronavirus pneumonia imported into Korea from Wuhan, China: implication for infection prevention and control measures. J Korean Med Sci 2020;35:e61.

4 Holshue ML, DeBolt C, Lindquist S, et al. First case of 2019 novel coronavirus in the United States. N Engl J Med 2020;382:929-36.

Cite this article as: Zhou Y, Ding N, Hu M, Yang G. The positive of stool test for SARS-CoV-2: a report of 9 cases in Changsha, outside Wuhan, China. Ann Transl Med 2020;8(9):596. doi: 10.21037/atm-20-2165
5 Zhang H, Kang Z, Gong H, et al. The digestive system is a potential route of 2019-nCov infection: a bioinformatics analysis based on single-cell transcriptomes. bioRxiv 2020. doi. 10.1101/2020.01.30.927806.

6 Chowell G, Abdirizak F, Lee S, et al. Transmission characteristics of MERS and SARS in the healthcare setting: a comparative study. Bmc Med 2015;13:210.

7 Chen N, Zhou M, Dong X, et al. Epidemiological and clinical characteristics of 99 cases of 2019 novel coronavirus pneumonia in Wuhan, China: a descriptive study. Lancet 2020;395:507-13. 